[澱粉科学 (J. Jap. Soc. Starch Sci.) 第 27 巻 第 2 号 p. 165 166(1980)]

\title{
タカアミラーゼ $\mathrm{A}$ の結晶構造解析と 分子構造 (3̊ㄱ分解能) \\ 松浦良樹*・楠木正己*・伊達和嘉子* 原田繁春*・田中信夫*・角戸正夫*
}

\author{
Molecular Structure of Taka-amylase A at $3 \AA$ Resolution \\ Yoshiki MatsuUra, Masami KUSUNOKI, Wakako DATE, \\ Shigeharu HARAdA, Nobuo TANAKA and Masao KAKUdo \\ Institute for Protein Research, Osaka Univ. \\ (Yamada Kami, Suita 565, Japan)
}

われわれはタカアミラーゼ $\mathrm{A}$ (澱粉の $\alpha$-アミロースを 加水分解する酵素) の結晶解析を進めてきたが (S.52年 会で $7.4 \AA$ 分解能の結果報告), 最近 $3 \AA$ 分解能での解 析を行い, 分子モデルを作成したので報告する. タカフ ミラーゼ Aの結晶は単斜晶系 P 21 に属しているが, 非 対称単位の 3 分子は [101]に平行なローカルな 31 らせ んのまわりに配置している. また同型置換重原子の探索 により，以前に見つかっていた $\mathrm{UO}_{2}\left(\mathrm{NO}_{3}\right)_{2}, \mathrm{HgCl}_{2}$ の 他に $\mathrm{K}_{2} \mathrm{PtCl}_{4}, \mathrm{~K}_{2} \mathrm{Pt}(\mathrm{CN})_{4}, \mathrm{AgNO}_{3}, \mathrm{~K}_{2} \mathrm{PdCl}_{4}, \mathrm{KAu}(\mathrm{CN})_{2}$ が比較的良好な同型置換体を与えることを見出し, 解析 飞利用した。 とくに非対称単位の 3 分子の相対位置は, これらの重原子のタカアミラーゼA分子への結合位置か ら最小二乗法によってかなり正確に決定することができ た. 分子座標系に基づた非対称単位の各分子の電子密 度図は, こうして得られた相対座標変換式に従い, 各点 の電子密度を結晶座標電子密度から線形補間することに よって得られた。

$3 \AA$ 分解能の最良電子密度図は, $\mathrm{U}$ と $\mathrm{Hg}$ の他に $\mathrm{Au}$ の置換体を用いて決定した位相 $(6 \sim 3 \AA)$ と他の重原子 も含めて決定した位相（30〜6 $\mathrm{A} ）$ とに基づいて計算した. $6 \sim 3 \AA$ 分解能での重原子パラメーターの精密化は, $\sin \theta$ /入に対してほぼ均一の反射数を含むように選択した， 総数の約 $1 / 4$ の反射を用いて多重同型置換最小二乗法に より行った. 精密化の概略をまとめて表 1亿示す.リチ ヤーズ箱によるワイヤ分子モデル作成のため，3つの分 子座標上の電子密度図を平均し, XY プロッターで $1 \AA$
〜 $2 \mathrm{~cm}$ のスケールで全体を分子長軸方向に 2 分割して 別々に等高線を描いた。 これは約 $80 \times 40 \AA$ の分子を $45 \times 45 \AA$ 相当のリチャーズ箱を利用して組みたてるた めである.このため分子モデル台はレールの上に載せ移 動可能とした．分子全体の電子密度図をこの $1 / 8$ スケー ルの積層板に描き，充分吟味した結果，ポリペプチド鎖 の流れを追らことができた．３分子の電子密度図を平均 することにより図は非常に見やすくなった．ワイヤモデ ル作成（図 1) により得られた主な結果は，1)分子を構 成するアミノ酸数は 452 である (今後, 多少の増減は考 えられる)．2）糖鎖は分子の活性部位のらしろ側でポリ ペプチド鎖から分岐している. 3) 4つのジスルフィド結 合は明瞭に認められた．4） $\alpha$-ヘリックスは全体の約 20 \%である. 5) 2 か所に $\beta$-シート様の二次構造がある.

6)酵素活性部位にはヒスチジン, リジン，アスパラギン 酸, チロシンなどが分布している.

表 1 .

\begin{tabular}{lccc}
\hline 分解能 $(\AA)$ & $\langle\mathrm{m}\rangle$ & 反射数 & 誘導体数 \\
\hline $30 \sim 7.4$ & 0.94 & $3,200(1,932)^{* 2}$ & 7 \\
$7.4 \sim 6$ & 0.82 & $2,700(1,630)^{* 2}$ & $4^{* 1}$ \\
$6 \sim 3$ & 0.67 & $39,600(9,166)^{* 2}$ & 3 \\
Total & 0.73 & $45,500(31,070)^{* 3}$ & \\
\hline
\end{tabular}

*1 U, Hg については異常分散考虑.

*2（）内は精密化に用いた反射数.

*3（）内は best フーリエ合成に用いた反射数.

* 大阪大学蛋白質研究所（565 吹田市山田上） 


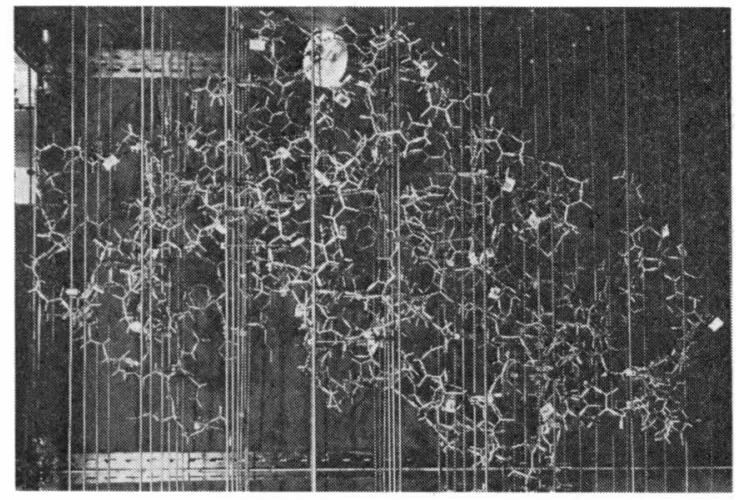

図 1. タカアミラーゼ $\mathrm{A}$ の分子模型

【質問】大阪府科学教育センター, 大阪府大 小野

TAA の結晶解析のご成功おめでとう存じます。活性 中心近傍の基質の入り込むすき間についてですが，さき ほど捄話しのマルトースのつかまる場所は，すき間のな

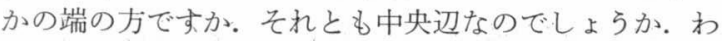
れわれは構造不明の期間に速度論的に勝手な推定をして きました。それによればすき間は lysozyme の 6 units に対して TAA は 7 units くらいとなっていますが，結 晶構造の解析からその数は reasonable でしょらか.

\section{【答】}

分子中央には，深い溝と浅い溝がありますが，そのな かの深い溝の中央部にマルトースが結合いたします（次 の質問に関しては廣海先生の質問に対する解答と同じ).

\section{【質問】}

東大 中村

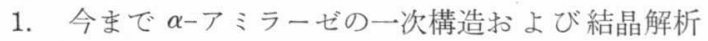
がなされなかったのは, 分子量が大さいといら理由だけ か，それとも特殊な困難の原因があるのでしょらか？

2. 活性基に関係するアミノ酸としてどのようなもの が推定されますか？

\section{【答】}

1. タカアミラーゼの 1 次構造は, 成田教授（阪大蛋 白研）によって研究されて拈り，大部分が決定されてお ります. 結晶解析が今まで行われなかったのは，1)分子 量が大きいこと，2)同一分子が 3 個集まって結晶学的な 単位を作っているため, X線解析で決めなければならな い構造が非常に大きくなる。などが理由かと思います。 なお，ブタのすい臓の $\alpha-$ アミラーゼの結晶解析がフラ ンスで進行中とのことです.

2. 現在までにわかったところでは, His が $\alpha-1,4-$ 結合の切断位置と推定しているところの近くにあります。 その他, Asp, Lys, Glu, Tyr むこの付近にあります。

\section{【質問】} 京大農 廣海

溝は直鎖の基質が伸びた形で結合できるような形でし ょらか(溝の幅と長さのサイズを教えていただけ机ば幸 いです).

\section{【答】}

分子の中央に深い溝があり，続いて浅い溝があります が，これらを合わせますと，直鎖の glucose が 7 個入る と考光られます。 